\title{
The changing legitimacy of health and safety, 1960-2015: understanding the past, preparing for the future
}

Article

Accepted Version

Almond, P. and Esbester, M. (2016) The changing legitimacy of health and safety, 1960-2015: understanding the past, preparing for the future. Policy and Practice in Health and Safety, 14 (1). pp. 81-96. ISSN 1477-4003 doi: https://doi.org/10.1080/14773996.2016.1231868 Available at https://centaur.reading.ac.uk/68073/

It is advisable to refer to the publisher's version if you intend to cite from the work. See Guidance on citing.

To link to this article DOI: http://dx.doi.org/10.1080/14773996.2016.1231868

Publisher: Taylor \& Francis

All outputs in CentAUR are protected by Intellectual Property Rights law, including copyright law. Copyright and IPR is retained by the creators or other copyright holders. Terms and conditions for use of this material are defined in the End User Agreement.

www.reading.ac.uk/centaur 
Central Archive at the University of Reading

Reading's research outputs online 


\section{The Changing Legitimacy of Health and Safety, 1960-2015: Understanding the Past, Preparing for the Future}

\section{$\underline{\text { Abstract: }}$}

'Health and safety' currently has an image problem in the UK. This article explores the origins of these current negative perceptions, framed around the concept of legitimacy - the degree to which a policy project of this sort is viewed as right, proper, and appropriate. The article considers and evaluates key moments in the growth and decline of social consensus around health and safety since 1960, including the Robens Committee and subsequent Health and Safety at Work etc Act, the decline of trade unionism, the extension of health and safety beyond the workplace, and the rise of the safety profession. It concludes that change has been much more subtle and less uniform than general perceptions might suggest, and makes recommendations for how public engagement with occupational health and safety might be restructured.

\section{Keywords:}

Commercialisation, expertise, Health and Safety at Work etc Act 1974, history, law reform, leadership, perceptions, policy recommendations, public image, regulation, trades unions. 
One of the most pressing concerns felt by many in the field of occupational health and safety recently has been the legitimacy, or the public profile and acceptance, of the regulatory system and of those who are active within it. Two recent, major, government-backed reviews of the health and safety regulatory system (Löfstedt 2011; Young 2010) highlighted the perceived problem of hostile and negative public perceptions in this area. Both reviews identified a widespread social climate of antipathy and mistrust towards the idea of health and safety and regulation within the UK. This concern led to the launch of a government-led public consultation on health and safety issues (the 'Red Tape Challenge' of 2011-13: http://www.redtapechallenge.cabinetoffice.gov.uk/about/), and to various Health and Safety Executive (HSE, the UK's national health and safety regulator) initiatives to engage with negative coverage and stories about the 'problem' of health and safety (including a 'Mythbuster' challenge panel: http://www.hse.gov.uk/myth/index.htm). The central issue these processes have been seeking to engage with is the narrative of 'health and safety gone mad' found in mainstream media coverage, in political debate, and in other manifestations of the 'public consciousness' (Almond 2009; 2015). The public profile of health and safety is thus perceived to be poorer now than it has perhaps ever been. 
This suggests a need to consider whether a fundamental shift has taken place in the current state of affairs surrounding health and safety in the United Kingdom. Health and safety has long been a key feature of the modern welfare state and of contemporary industrial relations; it formed a central part of the protectionist and paternalist reform movement of the $19^{\text {th }}$ Century that sought to address the social costs of the industrial revolution (Bartrip and Fenn 1983; Carson 1979; Long 2011; MacDonagh 1958; Mills 2010; Thomas 1948; Ward 1962) and was also linked to both the post-war 'wave of humane feeling and high aspiration for the future' (Mess 1926: 33) that followed World War 1, and to the pursuit of welfare-oriented social citizenship rights via the extension of the welfare state after World War 2 (Tucker 1995). At each stage, so the narrative goes, improving health and safety became more established and embedded as a desirable part of modern life, and a consensus around the issue and the need for some degree of regulation and control emerged. This culminated in the Robens Report of 1972, which identified a need for reform to modernise the regulatory system so as to better reflect the 'natural identity of interest' (Robens 1972: 21) between all parties involved in the area of health and safety, and the subsequent Health and Safety at Work Act 1974, which embedded a consensual, corporatist regulatory framework into law. 
While this framework has endured, there are grounds for suspecting that the wider social consensus around the issue, and the political settlement that enacted it, may have shifted decisively in recent years. While the critical climate of recent years looks and feels like a significant disjuncture with the past, there are also grounds for seeing it as part of a more long-term shift, as a climate of neoliberal politics and ideological rejection of regulation and welfarism has become gradually more entrenched since the late 1970s (Harvey 2005; Tombs and Whyte 2010; Tucker 1995), and the mechanics of state-based regulation have shifted to reflect the terms of a 'new public management' centred on increasing efficiency, Ministerial oversight, and regulatory accountability, and reducing material regulatory capacity (Baldwin and Cave 1999; Hood 1991). At the same time, it cannot necessarily be taken for granted that the degree of criticism that attaches to 'health and safety' now is greater, or more fundamental, than that encountered in the past. There is a need, as a result, to assess both the direction and extent of change, and to identify whether the drivers of change might lie at the institutional and political levels, or more in the social and cultural context against which systems of health and safety regulation operate.

The aim of this paper is to communicate a set of historically-grounded observations on contemporary trends in the public profile of health and 
safety, and a series of lessons learned that may be of value to those who are concerned about these issues. Studying regulatory history is a fundamentally valuable means of better understanding the present, and learning for the future (Balleisen and Brake 2014; Berridge 2010; Cox 2013; History and Policy 2015). The first section of the paper will outline and review the concept of regulatory legitimacy, and the contested nature of health and safety, both now and in the recent past. In particular, the core issues of public acceptance and political priority will be explored. The second section will then seek to outline the core methodologies of the study, briefly highlighting the use of mixed methods and the scope of the inquiry. The third section will identify the most significant social and historical developments that have had a bearing on the way that health and safety is perceived by the public and is categorised and prioritised as a political issue. Particular attention will be paid to those issues that are directly relevant to the debates and areas of activity of safety professionals, representative bodies, and other actors in the field of health and safety practice. The final section will set out what implications this account of historical development has for the future of health and safety practice. It will make pragmatic suggestions as to the ways in which the public presentation of health and safety might be re-imagined in the future, as a result of the lessons of the recent past. 


\section{1) Health and safety and the struggle for legitimacy}

Legitimacy is a complex and multifaceted social science concept which reflects the value that is attached to a social institution by the different bodies and audiences that are subject to its decisions or that interact with it (Beetham 1991; Suchman 1995). It provides a conceptual basis for assessing the 'social standing' that an issue like health and safety might enjoy. Unlike many other studies of regulatory legitimacy (Black 2008; Murphy, Tyler, and Curtis 2009; Tyler 2011), this investigation has attempted to trace the standing of a nebulous idea ('health and safety') rather than a particular agency (such as HSE), and has looked at the judgements made by the various social audiences of that idea, not just those who are subject to regulation. Legitimacy is defined by Suchman as a 'generalized perception or assumption that the actions of an entity are desirable, proper, or appropriate within some socially constructed system of norms, values, beliefs, and definitions' (1995: 574), and as taking three main forms: cognitive (it is believed to be inevitable or necessary), pragmatic (it is believed to be factually beneficial), and normative legitimacy. It is this latter form that encompasses the different value judgements that might be made about an idea or system of rules like 'health and safety'. A key distinction can be discerned here between recognising the legality of a decision, i.e. it is arrived at properly, and the rightness of that decision, i.e. it is morally 
justified (Beetham 1991). Black (2008) breaks these down into four areas of value judgement: constitutional claims (due process, valid authority, legal mandate); functional claims (efficiency, expertise, consistency); justice claims (rightness, fairness, social value); and democratic claims (participatory, open, reflects public preferences). Each matters, and each can be explored in turn.

We can begin to trace the influence of debates around legitimacy when we sketch out some of the key features of recent debates and public controversies around the field of health and safety. Political leaders have increasingly attacked the issue of health and safety; in 2008, while in opposition, David Cameron stated that “...this whole health and safety, human rights act culture, has infected every part of our life ", and by 2012, he was describing his "New Year's resolution: to kill off the health and safety culture for good. I want 2012 to [be] the year we get a lot of this pointless time-wasting out of the British economy and British life once and for all". ${ }^{2}$ Health and safety has been subjected to repeated review and reform during the five years of coalition government since 2010 (Almond 2015; James, Tombs, and Whyte 2013). The way that matters of 'health and

\footnotetext{
${ }^{1}$ Speech to Conservative Party Conference, reported in The Guardian, 01/10/2008; (http://www.guardian.co.uk/politics/2008/oct/01/davidcameron.toryconference1) [Accessed 05 May 2015].

2 'Coalition plans to kill off 'health and safety monster' with limits on lawyers' fees', reported in The Telegraph, 05/01/2012

(http://www.telegraph.co.uk/news/politics/8995276/Coalition-plans-to-kill-off-health-andsafety-monster-with-limits-on-lawyers-fees.html) [Accessed 05 May 2015].
} 
safety' are reported in the popular media, particularly print newspapers, has also become increasingly hostile. The Löfstedt Review expressed concern about the effects of $a$ 'constant stream of stories in the press blaming health and safety...for preventing individuals from engaging in socially beneficial activity, overriding common sense and eroding personal responsibility' (2011: 16). Cumulatively, these sources might indicate that the societal consensus about the progressive value of health and safety that underpinned the Robens report (1972) and the Health and Safety at Work Act 1974 has been eroded or reversed.

Additionally, a vocal anti-regulatory lobby has called for the removal of health and safety burdens via the consultation processes associated with these government reviews, and via a Government-backed 'Business Taskforce', which categorised the EU's Health and Safety at Work Framework Directive as a 'barrier to starting a company and employing people' (Business Taskforce 2013: 22). While the Löfstedt Review, and subsequent Temple Review of HSE (Temple 2014), a triennial government review of HSE's function, gave formal support to the existing health and safety regime, these processes of review provided a platform for debates about the fundamental value of state-led health and safety regulation, and about the proper balance between economic competitiveness and protectionist intervention. Indeed, historical analysis clearly identifies that 
these debates, and others of a political or ideological nature, have always underpinned the area of health and safety protection to varying degrees (Almond and Esbester 2016; Bartrip and Fenn 1983; Carson 1979; Esbester, forthcoming; Long 2011; McIvor 2013; Thomas 1948; Ward 1962). Health and safety regulation is, and has always been, a political issue, and so it becomes important to ask whether this current period and climate represents something new, or reflects longer-term tensions in the regulatory state.

Health and safety is contested on the basis of how it operates (functional), on what authority (constitutional), but also on the basis of why it operates (justice), and whose interests it represents (democratic). Crucially, it is not common for specific bases for these judgements to be spelt out in explicit terms. The study undertaken must identify and pull apart these differing currents of evaluation to analyse and make sense of them. At the same time, however, the society and phenomena being regulated have changed as well; British society, and the British workplace, are profoundly different now to how they were in 1960 or 1974 . The structure of employment within Britain has changed, with shifts from manual, industrial jobs to office-based roles, greater proportions of women working, and greater prominence for working practices beyond a 'standard' working week based at one physical location (including more flexible arrangements, like part-time working or work from home). In addition, workplace technologies have changed dramatically, 
along with new awareness of issues, both physical (such as musculoskeletal) and psychosocial (such as stress). These changes have posed significant challenges for regulators, duty-holders, and others.

\section{2) Scope and methodology of the current study}

The research project on which this paper is based utilised a mixedmethodology approach to gather a rounded overview of the way that health and safety has been understood and evaluated by policymakers, the public, and society as a whole over the last 60 years. The project has endeavoured to synthesise the findings of all of these methodological components to produce a single, coherent, narrative of change over time. Firstly, in order to generate new insights into historical processes, and to gather evidence about the judgements and decisions made at different points in time, a series of interviews $(\mathrm{n}=40)$ with key stakeholders and historical actors was undertaken. The participants were recruited because of their range of experiences and prominence in key areas, and in order to ensure that a range of constituencies were represented (regulators, policymakers and politicians, trade union actors, safety professionals and representative bodies, and employer and business actors). Each interview adopted a semi-structured approach, with a series of questions around which the participant was 
encouraged to direct and develop the discussion according to their own priorities and recollections.

Secondly, as this is an historical study, it was necessary to engage with a wide range of qualitative historical, archival, and documentary sources. Although limited by the survival and preservation of documents as well as access restrictions on material under 30 years old, material consulted was produced by state bodies, trades unions, employers' organisations, workers, the media and non-governmental organisations such as the British Safety Council and the Royal Society for the Prevention of Accidents (RoSPA). Records were selected by availability and a process of initial sampling to gain a broad overview, followed by more concentrated focus on areas identified in oral history interviews and focus groups as of particular importance. Thirdly, it was necessary to take account of current public attitudes, and so a two-pronged investigation was undertaken. Existing data sets and empirical studies have been systematically reviewed and analysed by a team based at Nottingham University (Jain and Leka 2015). To augment this quantitative data, a series of focus groups $(n=8)$ were conducted with members of the public $(n=67)$ to discuss perceptions and attitudes towards the idea of health and safety. These focus groups were conducted in different geographical locations across the country, with participants who were sampled to ensure broad demographic 
representativeness. They were structured, in that a common outline for discussion was utilised in each, and were analysed via an open coding framework.

\section{3) Key issues and developments affecting legitimacy}

A wide range of social and historical developments have had a bearing on the way that health and safety is regarded; the parameters of the discussion here will set out the most significant issues and also those that a professional body like IOSH and its members can influence and address (such as the agency of individual actors, the framing of debates, and access to government), rather than those (like the decline of manufacturing, or wider social/demographic/economic shifts) that they cannot. These four main areas of coverage will be explained in turn, with their key features summarised as a means of showing the direction and scope of the wider project.

\section{A: Constitutional Challenges: The Status of Regulators and the Law}

Much of the existing literature on regulation and legitimacy suggests that it is vital to understand and take account of the formal, constitutional and legal bases on which power is exercised and decisions are made (Baldwin 1995; 
Black 2005; Tyler 2011). The institutional mechanisms of regulation impact primarily upon the perceptions of those who are regulated (via, for example, the style and outcome of interactions with regulators); since this study is concerned with wider political and social legitimacy, it has focused on the components of constitutional structure that speak to the broader public and political constituencies of health and safety.

\section{A single, central, unified regulator?}

It might be suggested that while something was gained in amalgamating multiple inspectorates into a single body after the HSWA, in terms of procedural and organisational clarity and consistency, and direct accountability and oversight, something was also lost, in that the new body a) lost some of its traditional grounding and autonomous capacity (it became a little more distant from its regulated population); and b) it became a larger, more substantial, more wide-ranging organisation, with the associated pressures and scrutiny that that brought. In an effort to alleviate some of these pressures, HSE's Chief Inspector of Factories, Jim Hammer, suggested in 1975 that the HSE's strategy of political containment and consensus-building should be 'defusing criticism before it came by "selling" the organisation to MPs in times when it was not under attack due to the occurrence of a particular incident' (HSE Management Board 
Minutes, 1975). No sooner had the first wave of organisational changes bedded in, than a second wave of changes had to be negotiated; following the Clapham rail crash and the Piper Alpha disaster, HM Railways Inspectorate and the responsibility for regulating and inspecting offshore installations were shifted into HSE (in 1990 and 1991), mainly as a means of addressing some perceived conflicts of interest that undermined the legitimacy of those bodies in their previous departmental locations (Department of Transport and Department of Energy). This was also a means of depoliticising some aspects of regulation in these areas, postdisaster; arguably, this also had the effect of politicising some areas of HSE's work. In recent years, the Nuclear Installations Inspectorate and the Railway Inspectorate have shifted out of HSE once again; the interplay of commercial and protective pressures and responsibilities suggests that the regulation of safety in these areas is still subject to broader economic, political, and social pressures. As Hammer noted in interview:

"It was after Piper Alpha and the Cullen Inquiry that the offshore inspectorate came into the HSE...that of course brings up the whole business of who do you use to inspect a very specialist industry? All mines inspectors had to have been mine managers...That's very much poacher turned game keeper. It used to be similar for the railways. But the offshore inspectorate certainly depended on people's specialised knowledge just as we had our chemists and 
engineers. But I think we did our best to, as it were, train them in a 'control mode', to be independent. But of course they inspected their former colleagues and friends. It's not easy." (Jim Hammer interview, para.73)

The most profound element of division within the new regulator was that between the Health and Safety Commission and the Executive. The HSC was intended to act as the policymaking body which would give direction to the Executive. It was also the primary consultative and corporatist element of the system, and a political buffer between HSE and the wider political sphere. It provided a forum within which different interest groups, particularly the TUC and CBI, could be heard and consulted. In practice, this proved a reasonably constructive process, with a tendency towards seeking consensus and being led by the guidance of the HSE, but over time, this body came to be seen as something of a political liability; "Trades Unions' participation in government had been fashionable in 1972, but no longer was in 1992”, as one interviewee put it (John Rimington [DirectorGeneral, HSE 1983-1995] interview, para.73). By the late 1990s and early 2000s the HSC was attracting rather than deflecting pressure. Overall, it might be suggested that the new, unified HSE may be more equipped to act in a manner consistent with contemporary government norms of executive 
agency and managerialism, but less well equipped to liaise with external political constituencies.

\section{Regulators and government accountability}

HSE sits in a reasonably unusual place, constitutionally, within government; as a non-Departmental agency, it has a high degree of functional autonomy, something that was intended to help remove its day-to-day operations from the wider 'high' politics of industrial relations and economic policy (Moran 2003). At the same time, however, HSE remains answerable to central government via its sponsoring department, and thus accountable via budgetary controls as well as broader political priority-setting and pressure to address specific issues in particular ways. Interviewees, and archival materials, point to the influence that different Government preferences and ideology can have at particular times; that changes of government do filter down into differing approaches and demands on regulators, making it inherently political in its operations at times. One example issue highlighted has been the role of HSE as a regulator of areas where government, in one form or another, also holds the relevant duty (for example, in publiclyowned industries, or in regimes where approval has to be given for certain work practices). Offshore provides one good example of this, as does the Bilsthorpe Colliery collapse of 1993. 
At both ends of the line, the central concern here has been one of distortion over who is accountable, for what, and in what way? These issues are of primary importance for those who are involved in decisions about resourcing and supporting formal agencies, but also influence wider social attitudes (when, for instance, decisions are attributed to regulators that they had no hand in; Almond 2015). Central government has, over time, found that its capacity to exert centralised, politically-directed control over the workings of the regulator has conflicted with the reduced capacity to do this that exists within an arms-length arrangement (Baldwin 1995; Black 2008; Moran 2003). This may be linked to the emergence of a more critical, public-facing, and adversarial tendency around central executive attitudes towards health and safety and HSE, as well as to the rounds of Government review that HSE has faced at different times (the mid-1980s; the early1990s; and between 2010-14). At the same time, the regulator is held accountable (formally or informally) for the actions of others - selfregulating duty-holders, safety professionals, and other public bodies. So the problem is almost one of too much, rather than not enough, accountability; as perceived and actual responsibility outstrips the capacity to exercise control, the perceived legitimacy of health and safety suffers.

\section{The new legal framework}


The major change in the legal framework of the UK health and safety system was the HSWA 1974's movement from a largely prescriptive system of rules and specific duties to a more principles-based, goal-setting regime (Baldwin 1995; Robens 1972). This difference is generally regarded as one of moving from a system that told duty-holders what to do and how, to one that specified the outcome to be pursued (ensuring the health, safety and welfare of employees and others) but left the determination of how to fulfil this to duty-holders to decide (with due reference to industry standards and best practice, Approved Codes of Practice, and other forms of guidance). In 1977, for example, British Rail noted that the HSWA had 'already excited the imaginations of both managers and staff into a new awareness of the general safety problem. Since the employees themselves will be able to take the initiative ... it would be reasonable to expect a fresh new commitment by the staff to a major reduction in the accident rate of the industry' (British Rail, 'Fatal Accidents' memo, 1977: 10). Although sometimes contested (notably by trades unions), it is suggested that this model of flexible empowerment, rather than prescription, has had significant legitimatory effects re: the constitutional bases of regulation. ${ }^{37}$ Perhaps recognising this, an early stated aim of the HSC was to develop programmes stretching much wider than the regulatory framework, programmes designed to convince everybody at work of their personal responsibility towards health 
and safety which goes far beyond a formal compliance with the law' (HSC Health and Safety Bulletin, 1977: 1). Many interviewees discussed this shift, and linked it to two broader trends: the emergence of new areas of risk to govern, and the emergence of the safety profession. The primary legitimacy risk identified was that open-ended duties inherently encourage variation in practices, and some of this variation will inevitably tend towards the excessive; self-regulation places the decision-making burden onto third parties, and this allows for risk-averse decisions to be made within the scope of the health and safety regime (as undesirable as they may be). John Armitt, Chairman of National Express, and formerly Chairman of Railtrack and the Olympic Delivery Authority, commented:

"When this country moved from a regulatory regime such as still exists in countries like Germany to the risk assessment regime, to the ALARP regime, many people didn't like it because it required them to think. No longer could you say, 'oh, I'm doing it in accordance with the regulation or I'm doing it in accordance with the standard', you actually had to think about the specific task in hand and what were the risks and how did you lower those risks" (John Armitt interview, para. 9).

Additionally, the open-endedness of the law has been linked to increases in the volume of guidance and secondary material generated and available to 
duty-holders, and to an increase in the complexity and scope of the regulatory system (Baldwin 1995). A 1982 review of health and safety in the railway industry recorded that 'The proliferation of instructions on safety is a matter of concern to some managers who quote instances where it is sometimes necessary to consult several separate documents in order to find out how a job should be done' (British Rail, Outline Report, 1982: 17). Interviewees recognised that a principles-based system necessarily leads to some loss of clarity, and suggested that this had impacted negatively upon the capacity and willingness of some duty-holders to (being 'forced to think' as a double-edged sword), as well as making the idea of health and safety subject to greater expert oversight, proceduralisation, and bureaucracy. In particular, many felt that this encouraged duty-holders to replicate the rulesbased, prescriptiveness of the pre-1974 regime within their own organisations, leading to risk aversion and poor decision-making. One facetious response in the agricultural sector protested 'I really do not know where to begin and end on this one. How far do we go? "Staff should not walk under ladders" or "Staff should take every care that they do not put their foot in a rabbit hole”!' (Land Settlement Association Memo, 1976) The focus group data suggests that this problem was seen and encountered widely in workplaces and everyday life - inflexible and overbearing written policies, rigid and formal internal $\mathrm{HR} / \mathrm{H}+\mathrm{S}$ officers, and a sense of pervasive managerialism characterised many accounts, and crucially, this was often 
located at local, not regulatory, levels. According to Kevin Myers, Deputy Chief Executive of the HSE

"my thesis is the prescriptive legislative regime that we've tried to do away with by the HSWA...is now being replaced, within parts of our society by, in the name of self-regulation, people writing their own proscriptive lists of what you can and can't and shouldn't, wouldn't, couldn't do." (Kevin Myers interview, para. 48).

\section{Europe and 'regulation from outside'}

Europe, and the influence of Europe, has been one of the primary sources of concern for policymakers and politicians with regard to the legitimacy of health and safety regulations (Baldwin 1995). Since the Single European Act 1987 s.118A, which set out Community aims and interests in standardsetting in the workplace, the EU has increasingly been seen by politicians, policymakers, and the media as a source of legislative interventions (most notoriously the 6-Pack regulations of 1992) and of a non-accountable bureaucratic over-reaching, and precautionary unreasonableness, which has fundamentally damaged the legitimacy of health and safety as a whole. Europe is often thought to be much more risk-averse than UK and US 'Anglo-Saxon' jurisdictions, and to favour precaution and prescription over

more 'proportionalized' and risk-based modes of regulation (Löfstedt 2011; 
Rothstein et al. 2015; Vogel 2012) and so Europe has been identified and targeted as a bastion of over-regulation, excessiveness, and unreasonableness in approach and outcome. So, one factor for deciding what should be included in the HSC's work programme for 1981-82 was the need 'to respond to, and where appropriate, seek to change European Community or other international initiatives, and to stimulate such initiatives where this will help to ensure that realistic and effective health and safety policies can be adopted in this country' (HSC Press Release, 1981).

On the other hand, empirical data suggests that the public remain pretty uninformed and unconcerned about the EU's role in this area, and the focus groups confirmed that there was very little connection made between health and safety and the EU. While there may be a wider anti-EU agenda in play in UK politics, this does not necessarily seem to implicate health and safety directly, rather the often similar-looking antipathy to this area of regulation probably stems from a similar political or ideological source. It is worth reflecting on the extent and depth of the toxic political legacy that association with Europe via the 6-Pack and other legislation has had for health and safety; the 1980s and 1990s, and a lurch towards Euroscepticism on the right of politics in particular during this time, 'poisoned the well' for domestic regulators, and has indirectly created significant legitimacy 
challenges around issues of mandate and accountability. John Rimington, Director General of the HSE 1983-95, remembered that:

“By 1986 'Europe' was producing regulations which HSE (under supervision from the Department of Employment and the Foreign Office) had to negotiate. Early European regulations had all been based on British models and this had been largely uncontroversial. However, as time went on, several strands of political phobia became engaged and entangled in the process. These were (1) dislike of 'European' interference in 'British' law; (2) the idea of the 'nanny state'; (3) the traditional Tory dislike of 'burdens on business' and susceptibility to the views of small companies. There was also (4) a more sophisticated objection to the idea of 'principled' as opposed to 'mandatory' legislation in the Anglo-Saxon tradition." (John Rimington interview, para. 66).

At the same time, analysis of the relevant legislation, of the information and experiences of policymaking in Europe, and the outcome of various disputes tends to suggest, the UK actually has much more agency in terms of EUlevel law-making than many accounts suggest, and has not necessarily been dragged in directions it did not want to go to the degree that some might suggest (Rothstein et al. 2015). On this reading, then, it might be suggested that the EU is a political factor shaping the legitimacy of health and safety, 
and an institutional factor, but has not been quite as relevant at a social or normative level.

\section{B: Health and Safety in a Changing World}

What are the main contextual changes that have reshaped the world in which health and safety arises as an area of risk, and is regulated? What effects have they had in terms of perceptions of legitimacy and the functional and democratic bases of 'health and safety' in the UK?

\section{The decline of traditional industry}

It is well documented that the period 1960-2015 has seen a major realignment of the British economy and workplace; traditional, manual, heavily unionised industries (manufacturing, heavy production, extraction/mining) have declined in terms of their scale and in the share of the workforce employed, and this has led to a number of effects, not least the reduction in the influence and power of traditional trade unions. One additional result has been a reduction in the perceived legitimacy of health and safety provision, as industries where there are clear and established risks, and long traditions of risk regulation, serve to reinforce the idea of regulation as socially valuable. This perception was widely reflected in the 
focus groups. Additionally, one of the strengths and enduring legacies of these traditional industries had always been that they acted as 'leaders' for the health and safety agenda, developing and disseminating new modes of risk management and expertise. Traditional heavy industries could represent themselves as carriers of a substantial body of expertise and influence, and thus engage with policymakers as partners within the broadly cooperative health and safety regime. In the absence of these 'leader industries', it may be harder in the future for those working in health and safety to establish the value of what they do. Jim Hammer reflected that

"The other reason why people are not so aware of the real importance of health and safety nowadays is that the big industries that used to cause the dramatic, serious accidents, the ship building, chemical works, and big steelworks, talking in general terms, don't exist anymore. Yes, I know I'm exaggerating, but people don't have this perception that it's important to defend, to look after working people because so many of them are just drivers and subject to the usual hazards of road traffic accidents." (Jim Hammer interview, para. 67).

As well as the shift away from key leader industries in safety policy, this change in the makeup of the British economy and workplace profile has also seen the emergence of new industries and sectors, which have their own challenges and political contexts. Certain of these (major retail, 
supermarkets, SMEs) are, it is suggested, now leaders in influencing the agenda of government. These workplaces also feature different challenging elements (subcontractors and supply chains, temporary and short-term contracts, mobile workforces). Crucially, it remains to be seen how traditional notions of 'health and safety' map across into these sectors, in terms of making the normative case for intervention, and showing that the delivery of effective health and safety provision is efficient, proportionate, and of value.

\section{The decline of Trade Unionism/Worker Representation}

One key feature of the changing industrial context of modern Britain has been the decline of trade union membership (Ebbinghaus and Visser 1999; Visser 2012). This decline has been reflected elsewhere in the absence of organised labour as a leading influence from policymaking and political processes. There have been wider social and cultural shifts in how labour protection is viewed, how policy is made, and how representation and worker engagement is undertaken. How far does a key role for unions remain in a post-industrial world (James and Walters 2002; Quinlan 1999; Walters 2006)? How does a decline in unionism affect the democratic legitimacy claims that are made on behalf of the idea of health and safety? It appears, at least from the initial indications, that unions retain the greatest 
influence in industries where health and safety is either a less immediately relevant factor (the public sector) or subject to specific risks and regulatory regimes (construction, extraction), hence engagement is bounded to these spheres rather than generalised.

Unionism has also been heavily politicised and contested during this period, bringing issues of 'high' politics into the workplace. Trade unions have, according to the data gathered, seen a reduction in their ability to influence outcomes and a marginalisation in policymaking spheres, from key partners within sometimes uneasy formal processes, to vocal, but external, critics. Health and safety has featured as a component of these wider industrial relations disputes, but perhaps not to the extent or degree that other issues (wages, conditions) have during the same time period. One explanation for this is that health and safety has remained a 'day-to-day' feature of business, via representative and consultative measures, and so a 'safe haven' in which trade unionism could remain relevant, active and fresh, even in times of conflict elsewhere. This was articulated by the General Secretary of the Amalgamated Union of Engineering Workers in 1972, claiming the trade unions made an 'extensive contribution' to accident prevention (Amalgamated Union of Engineering Workers Journal, 1972: 395). It was also the case, according to interviewees, that trade union involvement in safety was useful; as people who knew the area and issues, union reps 
carried a lot of expertise (often more than employers themselves). As Tim Carter, a former HSE official, recalled:

"it was not acknowledged, and what you see as soon as you're in HSE, actually on casework and working conditions, most union reps and shop stewards do their best to do a good job" (Tim Carter interview, para.105).

As trade unionism has declined, therefore, a lot of the impetus behind the promotion of health and safety as an issue has arguably been lost. According to Chris Marchese, Chief Operations Officer for Magnox Nuclear Ltd in the 2000s:

“in the last ten years there's been a gradual loss in influence, to the detriment of the management side I feel, from the loss of empowerment by trade unions. In the industry fewer people belong to trades unions...Because there are fewer trade union members their organisations are much smaller, so they are not in a position to support their own trades union representatives as much as they used to. We can make up for some of that, but because they're not pushing safety representatives enough...we struggle to get volunteers..." (Chris Marchese interview, para.53).

\section{C: What Should be Regulated, and How?}


There have been new and emergent disputes about the proper limits of 'health and safety' as a concept, and about the ways in which it should be implemented and addressed. Some of these extend beyond the formal regulatory system and demand attention in a study of the social phenomena of 'health and safety'.

\section{Health and safety beyond the workplace}

Perhaps the principal finding and area of interest re: the changing profile of health and safety has been the perceived influence and importance of the extension of regulation applied to occupational health and safety issues that have an impact beyond the workplace. This was massively extended by the HSWA 1974 s.3 (a new duty prompted in part by the experience of Flixborough and other disasters), but also arguably aided by the Offices, Shops and Railway Premises Act 1963's extension of the law to 'new entrants' and industries. In general terms, there is a recognition that, as the 1970s turned into the 1980s, more attention began to be paid to issues of health and safety in the wider world. A TGWU rep claimed that what was needed was 'a government-sponsored campaign...to sell safety to the whole community' (Industrial Safety, 1972: 410). Wider attention was paid to issues including asbestos, domestic gas supply (1985), violence at work, leisure facilities and public spaces (late 1980s), as well as major disasters 
that either affected the public (rail crashes like Clapham, 1988) or went beyond the 'factory fence' (prompted as well by the Seveso directives). From approximately the mid-80s onwards, a new focus on public safety is identified and reported, reflected in things like the development of HSE's Tolerability of Risk framework (HSE 1988), a new methodological interest in public attitudes, and a new politicisation of issues of public protection. Roger Bibbings, health and safety advisor at the TUC from 1977-1994, recalled that the Director-General of the HSE:

"invited me to come and present from a TUC perspective to get the discussion going amongst his senior colleagues. So I said, 'oh you need to look again at worker safety and so on'...not very long into this, he put his hand up and said, 'no, no, no, stop my boy, stop ...that's worker safety. That's a dead volcano', he said. 'The live volcano is public safety. That is what's going to energise everyone," (Roger Bibbings interview, para. 19).

Many interviewees expressed concern about the seemingly unbounded nature of these areas and duties, which went beyond what Robens/the HSWA had envisaged, and about the implications for practice (resources, the inapplicability of workplace-oriented standards and levels of expected compliance, the demands re: risk management being rolled out to unqualified people) and perception (that this was a key source of public 
frustration and perceptions of over-regulation). In particular, interviewees suggested that neither HSE nor HSC were equipped or ready to take these roles on, leading to areas of neglect, confusion, or resistance. The focus group data clearly highlighted this issue of overspill as a major concern that had fundamentally undermined perceptions of legitimacy and value - in workplaces, and 'genuine' risk settings, health and safety was seen as legitimate and valuable, but this did not extend to all areas of public and private life, and contributed significantly to perceptions of over-regulation. It was also noticeable that there were perceptions that certain sectors and workplaces were felt to fall outside the scope of 'legitimate' health and safety intervention by the public, by regulators, and by other interviewees.

\section{The emergence of the safety profession}

Another one of the main issues to have emerged is the development of the safety profession as a component of the contemporary health and safety landscape. While Robens and the 1974 Act envisaged a three-legged stool (state regulators, trades unions, employers), the safety profession occupies a conceptual space somewhere between these three constituencies; managing risks for and within employer firms, holding a normative commitment to worker well-being and a similarity of interest with trade unions, and occupying a quasi-regulatory role as standard-setters and compliance- 
monitors within a polycentric self-regulatory regime. What influence and impact have the new safety professions, which were starting to emerge in the first half of the $20^{\text {th }}$ century but which have gained traction and momentum since 1974, had upon the perceived legitimacy of the issue? Janet Asherson, Head of Health and Safety at the Confederation of British Industry 1989-2008, believed that

“Frankly, it's a consultant's paradise because it's got such low barriers to entry...there's nothing in it for a consultant to say there is no risk there. It's a very brave consultant who would ever say you're managing that $O K$. You can always find something that has to be done...it's frustrating to professionals but has also allowed the professional bubble to burst into society and be viewed by society and particularly the media to see those elements of taking things too far, making things too bureaucratic" (Janet Asherson interview, para. 52).

One short answer is that they have been perceived as a central component in the bureaucratisation and growth/pervasiveness of health and safety and risk-aversion, at least in the eyes of key witnesses (particularly regulators) and the public. They are seen as unregulated, often unskilled, and sometimes a barrier to good practice. Testimony to the Robens Committee recognised that safety professionals had 'to earn people's respect before 
they will expect much from us' but at the same time groups like RoSPA had, over the preceding few years introduced professionalism into the work [and] people are listening to us' (RoSPA, verbal evidence, 1971: 5). The positive impact in raising overall standards, and in filling the gaps left behind as union engagement and membership recedes, was also acknowledged; the training, professionalization, and systematisation of the professional has been recognised as a key factor in improving overall rates of injury etc. But this remains a limited acknowledgement. Public attitudes tend to regard the 'safety guys' as boring, jobsworths, people who meddle and make life harder (Pidgeon et al. 2003) - as early as 1971 RoSPA observed that there was a public image problem around health and safety, an issue seen as 'stuffy' (RoSPA National Publicity Committee minutes, 1971: 5). But it is worth noting how embedded the safety profession was in our interview sample; almost all now in the field of the 'safety professional' or representative body had experience or background in either regulatory or trade union settings, or had come to it via those routes; many in business or in regulatory settings had safety profession memberships, and many were also very aware of one another's roles and interests - there is a high degree of interdependence, overlap, and cooperation with these other constituencies.

\section{The value and importance of Expertise}


One key factor that seems to be vital in determining the perceived functional legitimacy of health and safety as an idea is the relationship between risk and expertise. Health and safety intervention is respected and seen as necessary or desirable when it is linked to a strong basis in expertise; focus groups and other public attitude sources point to the centrality of expertise (measured, demonstrated, certified, and experiential) to the assessment of the legitimacy of regulators and safety actors (Black 2008; Pidgeon et al. 2003; Tyler 2011). The single most influential cited factor shaping whether members of the public would listen to, respect, and cooperate with, a 'safety professional' or advisor, was the perceived level of experience and expertise of that individual. An offshore inspector noted of the 1980s and 1990s that working relationships were good because offshore workers and managers "knew exactly what our job was, they knew that we were professional people...with engineering backgrounds, we understood what they were trying to do" (Martin Thompson interview, tape 2 side b). Expertise has an enduring, robust, and pervasive importance to issues of legitimacy; it establishes credentials for intervening and for reordering the world.

There is a more negative associated effect of this expertise; that it leads to bureaucratisation and unnecessary paperwork. In the early 1980s an investigation into British Rail's implementation of the HSWA noted that 
some managers 'are dismissive about the [local OHS] statements regarding them as a paperwork exercise which add little to BR's existing safety effort' (British Rail, Outline Report, 1982: 1). There is also a concern that expertise creates systematic, instrumentalised approaches to safety based in technical and impenetrable mind-sets that are hard for lay people to understand, and which create a distance between 'health and safety' and regular people. A 1977 British Rail memo noted enthusiasm for health and safety generated by the HSWA, but followed it with a warning: 'It would be a tragedy if, instead, implementation of the Act became a battlefield of disagreement on...unreasonable safety standards' (British Rail, 'Fatal Accidents' memo, 1977: 10). This way of seeing, in actuarial terms, is also identified at a regulatory level; the trends towards targets, probabilities, quantification, and proceduralism (Black 2008), while necessary from the point of view of efficiency and effectiveness, also have costs in terms of the 'jargon' and accessibility of the measures and systems that they establish, and thus on degrees of acceptance and cooperation, as recognised by Helen Leiser who worked at senior levels in both the HSE and Department of Trade and Industry:

"one of the dilemmas for the health and safety organisations and the HSE now is actually it's a little bit beyond the frame of people's day to day preoccupations. People have strong views about the regulations on cycles using main roads or cycle tracks and so on 
because you see that every day...but whether people would really have a considered view about the relevance of particular legislation, I'm not sure” (Helen Leiser interview, para. 110).

\section{D: Justice Challenges: Whose Values Underpin Regulation?}

The last area to explore is the idea of justice-based legitimacy; how far is protecting worker safety and health, and the welfare of others, seen as the right thing to do, and consistent with wider social values?

\section{Commercialisation}

One tension in decisions about what is desirable and justifiable in this area, is the impact of a trend towards commercialisation upon perceptions of health and safety as an issue. On the one hand, the public perception, gathered via the focus groups, was that the linking of safety issues to the pursuit of profit was toxic, in terms of perceptions. The more it was seen as a 'job creation exercise', as self-serving, and as a service that was paid for rather than undertaken for genuine moral reasons, the greater attitudes towards health and safety hardened and became more hostile. It turns out the only thing more disliked than a health and safety jobsworth is a health and safety jobsworth who is in it to make money. This concern about 
commercialisation was mirrored elsewhere, with others such as Roger Bibbings suggesting that issues like FFI and other approaches would undermine the credentials and effectiveness of the regulator:

"HSE has become a service delivery organisation, its mission has changed...HSE is being turned into a delivery agency with a significant element of self-funding...what is lost in that potentially is the ability of the civil servants who run it to basically think about improvement and think about how things can be done differently and better. And I think there's a great danger at the moment that HSE will not be able to, if it is purely a delivery agency, to exercise the level of creativity required to take health and safety forward" (Roger Bibbings interview, para. 35).

For the most part, stakeholders tended to indicate that they saw commercialisation as a legitimate means of extending the reach of the regulatory system, and thus as a good thing. But this balance is difficult, because doing so does change the terms and conditions on which health and safety engagement occurs. Public attitudes to tend to suggest that the moral stance of those in the field is one of the key strengths that those bodies and agencies have; this is lost when there is a sense of undue commercialisation. The other aspect of commercialisation is the notion that it renders health and safety a service to be paid for, rather than a process to invest in - that 
companies outsource it, and pay lip service as a result. According to one offshore inspector, within the HSE "there was unease...because we felt that...if a company has to pay for coming along and having a meeting with us to talk about something where they're going to be proactive in terms of health and safety that that might actually discourage these sort of meetings, you know, and...the full interchange of information" (Martin Thompson interview, tape 4 side a). There is a need for this relationship to be reviewed and for ways of resetting or pitching the role of the external advisor or expert in a way that avoids this toxic association.

\section{The Limits of Consensus?}

There is ample evidence of a breakdown of political consensus around the issue of health and safety, at least at the level of party politics, ideology, and media coverage. Many interviewees testified to the contested nature of policy in these areas, and the changing political fortunes of "health and safety' at different times. As well as the ideological and policy preferences of Ministers and governments there is a perception of a broader political shift towards the language and terminology of a neoliberal settlement (Almond 2015; Harvey 2005; James, Tombs, and Whyte 2013; Tombs and Whyte 2010), something that goes beyond immediate policy issues, and beyond health and safety itself, to encompass a new way of seeing the 
world. Different governments approach this differently, but the climate has hardened, not just with regards to accountability and reviews (Hood 1991), but to a broader rejection of a welfare-oriented outlook, as noted by Lawrence Waterman, Director of Health and Safety for the Battersea Power Station development and formerly Head of Health and Safety for the Olympic Delivery Authority:

"it [health and safety] never really got on the Conservative Party agenda, and ever since they've been... 'God, we really didn't mean to join Europe and we'd like to leave'. 'We didn't really mean to support the Health and Safety at Work Act and we'd like to move backwards.' So why not express it in those terms? Because that would make them sound as though they're callously indifferent to injuries to workers, which they probably, in the main, are" (Lawrence Waterman interview, para.10).

That said, public attitudes do remind us of the need to separate these political currents and trends from the general attitudes and preferences of the public; there remains a deep-rooted acceptance of the idea of health and safety, and recognition of the right to safety. These preferences are embedded beneath a layer of negative public opinions, which obscure them, but consideration of the issues does reveal these more considered positions and views. This is also, to some degree, true also of the political sphere - 
health and safety is not really ever rejected outright as an important area, except by the most extreme sceptics. Health and safety does retain a grounding of popular and political acceptance and support. The project is not as badly perceived as might be thought. There remain areas where conflicts arise, and these do tend to cluster around pinch points where the needs of the job, and the tension between safety and profit, collide. While this has long been the case, there is evidence that these tensions do remain. On the other hand, this opens doors for improvement where the business case for safety can be demonstrated.

\section{4) The policy implications of these developments}

So what are the implications of this account of change over time for the future of OHS practice and regulation? A number of suggestions for a restructuring of public engagement around the issue of OHS can be made:

i. Public perceptions of health and safety have two tiers; opinions (immediate, critical, transient), and attitudes (considered, positive, enduring). When people stop to think about what health and safety means, their attitudes are much less critical. It is important for those

engaged in 'selling' health and safety to separate 'signal' from 
'noise'; this might also caution against over-engagement with 'regulatory myths' (Almond 2009).

ii. Despite changes to the world of work, there are still audiences and demands for health and safety in offices and service-sector industries, which need to be approached in new, context-specific ways. Resistance generally concerns the 'low politics' of local issues, while the 'high politics' of the ideal remains relevant. Those working in health and safety should not avoid making moral arguments about its value.

iii. Expertise remains a fundamentally important feature of 'good' regulation and health and safety. Developments here (like the exporting of expertise from the UK to other jurisdictions) are potential tools with which to leverage legitimacy. Universities provide an example of 'selling' the value of contributions to the global knowledge economy within domestic political debate.

iv. Where there are issues of legal and structural form (the EU, or the open-ended duties in HSWA 1974), there has perhaps been a tendency to play these issues down or distance 'health and safety' from implication. It may be time to consider presenting these steps 
more directly as success stories, rather than as potentially toxic heritage: 'health and safety: where the UK got its own way in Europe'.

v. As traditional 'leader industries' decline, there is a need for new leaders to emerge as contexts where i) the benefits of regulation can be made explicit, and ii) new modes of working and risk management can be developed and disseminated. The construction and agriculture industries have the potential to perform this role, not because of their spotless records, but because they can demonstrably reinforce the fact that health and safety matters.

vi. Commercialisation of health and safety needs careful management; it erodes the most fundamental pillar of public legitimation that the idea of health and safety possesses - the sense that it is for the public good and undertaken for the public good and with humanitarian motives in mind. The safety profession, and regulators, need to fight to retain this 'normative position', even as their roles change over time.

\section{Primary Sources}

Amalgamated Union of Engineering Workers Journal, September 1972. 
British Rail, 'An Outline Report on OSH', 1982. The National Archives of the UK [TNA], London, AN 16/157.

British Rail, 'Fatal Accidents to B.R.B. Employees', Memo to British Rail Board, 16 August 1977. TNA, AN 156/936.

HSC Health \& Safety Bulletin, 4 October 1977. Museum of English Rural Life [MERL], Reading, CR3LSA AD9/1/222.

HSC press release, 18 June 1981; Mitchell Library, Glasgow, TD914/18/2. HSE Management Board Minutes, 19 June 1975, Min. 2,a,i. TNA, EF 10/1. Industrial Safety, September 1972.

Land Settlement Association memo, 20 May 1976. MERL, CR3 LSA AD9/1/222.

Martin Thompson, interview for University of Aberdeen 'Lives in the Oil Industry’ project, British Library, London, C963/13.

RoSPA National Publicity Committee minutes, 22 September 1971. RoSPA archives, Birmingham, D.266/2/4/3.

RoSPA, Verbal evidence to the Robens Committee, 14 June 1971. TNA, LAB 96/75.

\section{References}

Almond P. The Dangers of Hanging Baskets: Regulatory Myths' and Media Representations of Health and Safety Regulation. Journal of Law and Society. 2009; 36/3: 352-375. 
Almond P. Revolution Blues: The Reconstruction of Health and Safety Law as 'Common-Sense' Regulation. Journal of Law and Society. 2015; 42/2: 202-229.

Almond, P and Esbester M. (Il)legitimate risks? Perceptions of occupational safety and health in post-1960 Britain, in T. Crook and M. Esbester (eds.), Governing Risks. Danger, Safety and Accidents in Modern Britain, c.1800-2000. Basingstoke: Palgrave Macmillan, 2016; 295314.

Baldwin R. Rules and Government. Oxford: Clarendon Press; 1995.

Baldwin R. and Cave M. Understanding Regulation: Theory, Strategy, and Practice. Oxford: Oxford University Press; 1999.

Balleisen EJ. and Brake EK. Historical Perspective and Better Regulatory Governance: An Agenda for Institutional Reform. Regulation \& Governance.2014; 8/2: 222-245.

Bartrip P, and Fenn PT. The Evolution of Regulatory Style in the Nineteenth Century British Factory Inspectorate. Journal of Law and Society. 1983; 10/2: 201-222.

Beetham D. The Legitimacy of Power London: Macmillan; 1991.

Berridge V. Thinking in time: does health policy need history as evidence? Lancet. 2010; 375/9717: 798-799.

Black J. The Emergence of Risk-based Regulation and the new Public Risk Management in the United Kingdom. Public Law. 2005; 512-549. 
Black J. Constructing and Contesting Legitimacy and Accountability in Polycentric Regulatory Regimes. Regulation \& Governance 2008; 2/2: 137-164.

Business Taskforce. Cut EU Red Tape: Report from the Business Taskforce, London: $\quad$ HM $\quad$ Government; 2013. https://www.gov.uk/government/uploads/system/uploads/attachment _data/file/249969/TaskForce-report-15-October.pdf

Carson WG. The Conventionalisation of Early Factory Crime. International Journal of the Sociology of Law. 1979; 7/1: 37-60.

Cox P. The Future Uses of History. History Workshop Journal. 2013; 71/1: $125-145$

Ebbinghaus B. and Visser J. When Institutions Matter: Union Growth and Decline in Western Europe, 1950-1995. European Sociological Review. 1999; 15/2: 135-158.

Esbester M. The Birth of Modern Safety. Preventing Worker Accidents on Britain's Railways, 1871-1948. Abingdon: Taylor \& Francis; forthcoming.

Harvey D. A Brief History of Neoliberalism. Oxford: Oxford University Press; 2005.

History and Policy. (2015) http://www.historyandpolicy.org/ [Accessed 30 April 2015] 
Hood C. A Public Management for All Seasons? Public Administration. 1991; 69/1: 3-19.

HSE. The Tolerability of Risks from Nuclear Power Stations. London: HSE Books. 1988.

Jain, A. and Leka, S. Occupational Health and Safety Legitimacy in the UK:

A Review of Quantitative Data. University of Nottingham: Nottingham; 2015

James P, Tombs S and Whyte D. (2013) An Independent Review of British Health and Safety Regulation? From Common Sense to Non-sense. Policy Studies. 2013; 34/1: 36-52.

James, P and Walters, D. Worker Representation in Health and Safety: Options for Regulatory Reform. Industrial Relations Journal. 2002. 33/2: $141-156$

Löfstedt R. Reclaiming Health and Safety for All: An Independent Review of Health and Safety Legislation [The Löfstedt Review]. London: Crown; 2011.

Long V. The Rise and Fall of the Healthy Factory: The Politics of Industrial Health in Britain, 1914-60. Basingstoke: Palgrave Macmillan’ 2011.

MacDonagh O. The Nineteenth-Century Revolution in Government: A Reappraisal. Historical Journal. 1958; 1/1: 52-67.

McIvor A. Working Lives: Work in Britain Since 1945. Basingstoke: Palgrave Macmillan; 2013. 
Mess HA. Factory Legislation and its Administration 1891-1924. London: P. S. King \& Son; 1926.

Mills C. Regulating Health and Safety in the British Mining Industry, 18001914. Aldershot: Ashgate; 2010.

Moran, M. The British Regulatory State: High Modernism and Hyper Innovation. Oxford: Oxford University Press. 2003.

Murphy K, Tyler T and Curtis A. Nurturing Regulatory Compliance: Is Procedural Justice Effective When People Question the Legitimacy of the Law? Regulation \& Governance. 2009; 3/1: 1-26.

Pidgeon, N. Walls, J. Weyman, A. and Horlick-Jones, T. Perceptions of and Trust in the Health and Safety Executive as a Risk Regulator [Research Report 100]. Sudbury: HSE Books. 2003.

Quinlan, M. The Implications of Labour Market Restructuring in Industrialized Societies for Occupational Health and Safety. Economic and Industrial Democracy. 1999; 20/3: 427-460.

Lord Robens. Safety and Health at Work: Report of the Committee 1970-72 (The Robens Report). London: HMSO; 1972.

Rothstein, H. Beaussier, AL, Borraz, O, Bouder, F, Demeritt, D, de Haan, M, Huber, M, Paul, R, and Wesseling M. When 'Must' Means 'Maybe': Varieties of Risk Regulation and the Problem of Trade-offs in Europe. HowSAFE Working Paper No.1. 2015. 
Suchman M. Managing Legitimacy: Strategic and Institutional Approaches. The Academy of Management Review. 1995; 20/3: 571-610.

Temple M. Triennial Review Report: Health and Safety Executive [The Temple Review]. London: HMSO; 2014. https://www.gov.uk/government/publications/triennial-reviewreport-health-and-safety-executive-2014

Thomas MW. The Early Factory Legislation: A Study in Legislative and Administrative Evolution. Leigh-on-Sea: Thames Bank; 1948.

Tombs S. and Whyte D. A Deadly Consensus: Worker Safety and Regulatory Degradation under New Labour. British Journal of Criminology. 2010; 50/1: 46-65.

Tucker E. And Defeat Goes On: An Assessment of Third-Wave Health and Safety Regulation, in: F Pearce and L Snider (eds.) Corporate Crime: Contemporary Debates. Toronto: University of Toronto Press; 1995, p.245-267.

Tyler TR. The Psychology of Self-Regulation: Normative Motivations for Compliance, in C. Parker and V.L. Nielsen (eds.) Explaining Compliance: Business Responses to Regulation Cheltenham: Edward Elgar; 2011: p78-102.

Visser, J. The Rise and Fall of Industrial Unionism. Transfer: European Review of Labour and Research. 2012; 18/1: 129-141. 
Vogel, D. The Politics of Precaution: Regulating Health, Safety, and Environmental Risks in Europe and the United States. Princeton University Press; 2012.

Walters, D. One Step Forward, Two Steps Back: Worker Representation and Health and Safety in the United Kingdom. International Journal of Health Services. 2006; 36/1: 87-111.

Ward JT. The Factory Movement 1830-1855 London: Macmillan; 1962.

Young D. Common Sense, Common Safety [The Young Review]. London: Crown; 2010. 